\title{
ANALISIS MOTIVASI GENERASI MUDA DALAM MELAKUKAN PERILAKU MENYIMPANG (STUDI KASUS PERILAKU SEKS PRANIKAH DI DISTRIK MALAIMSIMSA KOTA SORONG)
}

\author{
Nurhidaya \\ Prodi Sosiologi \\ Fakultas Ilmu Sosial dan Ilmu Politik \\ Universitas Muhammadiyah Sorong
}

Diterima:19 Oktober 2016. Disetujui:23 November 2016. Dipublikasikan:1 Desember 2016

\begin{abstract}
ABSTRAK
Penelitian ini didasari keinginan untuk mengetahui dan mendeskripsikan secara mendalam mengenai perilaku seks pranikah pada generasi muda khususnya mahasiswa yang ada di Distrik Malaimsimsa Kota Sorong. Penelitian ini merupakan penelitian deskriptif dengan menggunakan pendekatan kualitatif. Teknik pengambilan sampel dalam penelitian ini adalah dengan cara purposive sampling yaitu pemilihan siapa subjek yang ada dalam posisi terbaik untuk memberikan informasi yang dibutuhkan. Sumber data diperoleh melalui penyebaran angket kepada mahasiswa dan wawancara mendalam bersama tokoh agama serta tokoh masyarakat yang ada di Distrik Malaimsimsa Kota Sorong. Perilaku seks pranikah saat ini sudah menjadi fenomena pada generasi muda khususnya mahasiswa yang ada di Distrik Malaimsimsa Kota Sorong. Adapun motivasi mahasiswa melakukan perilaku seks pranikah diantaranya adalah atas dasar rasa cinta, hubungan yang dijalani sudah lama serta adanya unsur takut kehilangan. Selain motivasi, seks pranikah juga dipengaruhi oleh beberapa faktor, diantaranya faktor interaksi dengan teman dan pemilik rumah sewa (kost), lingkungan dan media, serta kurangnya control dan kunjungan orang tua, sehingga mahasiswa dapat melakukan segala sesuatunya dengan bebas termasuk perilaku pranikah. Maraknya seks pranikah yang dilakukan oleh generasi muda tersebut juga menimbulkan dampak tersendiri bagi pelakunya. Adapun dampak dari perilaku seks tersebut diantaranya adalah kehamilan di luar pernikahan, Terinfeksi penyakit seksual, membuat seseorang menjadi seksual person, yaitu ada saatnya ia merasakan ingin melakukannya kembali, pengguguran janin/aborsi, serta Perasaan takut ditinggal pasangan karena mereka merasakan ikatan yang sulit untuk dilupakan dan dilepas dengan pasangan yang sudah mengambil virginitasnya. Dalam hal ini selain orang tua dan lingkungan, pemerintah juga dituntut agar lebih serius dalam menyikapi kasus tersebut. Misalnya, dengan cara seringnya melakukan sosialisai seperti sosialisasi tentang program Penyiapan Kehidupan Berkeluarga Bagi Remaja (PKBR), program ini tidak lain sebagai antisipasi meningkatnya perilaku seks bebas di kalangan generasi muda saat ini.
\end{abstract}

\section{Kata Kunci : Motivasi, Perilaku Seks Pra nikah}

\section{PENDAHULUAN}

Kebudayaan bangsa yang dihormati dan diamalkan aspek-aspeknya dalam kehidupan sehari-hari bukan tidak mungkin akan terdesak dan semakin ditinggalkan oleh mereka yang sangat tertarik bahkan tergilagila dengan unsur-unsur budaya asing. Kenyataan menunjukkan bahwa orang timur yang terpesona dengan budaya barat cenderung memiliki gaya hidup yang 
kebarat-baratan dan antipasti terhadap budaya bangsanya sendiri. Salah satu nilai yang turut berubah adalah dalam hal seksual dengan segala macam segi dan permasalahan, yang membuat penghargaan terhadap nilai-nilai agama menjadi memudar dan berkurang, bahkan tidak menutup kemungkinan akan menghilang. Sehingga seksual yang dulunya dipandang merupakan sesuatu yang tabu, namun realitanya di Indonesia khusunya di Kota Sorong, perilaku seks yang umumnya dilakukan pranikah sudah menjamu dan bukan sesuatu yang tabu lagi melainkan sudah sampai pada tingkat yang mengkhawatirkan. Perkembangan yang demikian jika dibiarkan akan meluas dan dapat merusak generasi muda yang sangat diharapkan dapat mengemban fungsi kehidupan bangsa dan Negara yang lebih baik di masa mendatang.

Berdasarkan pengamatan awal yang dilakukan oleh peneliti, Distrik Malaimsimsa Kota Sorong merupakan salah satu kota dimana banyak terdapat generasi muda dengan berbagai macam permasalahan dan juga penyimpangan, salah satunya adalah mengenai seks pranikah. Namun dalam penelitian ini difokuskan kepada generasi muda yang berstatus sebagai mahasiswa dan belum terikat tali pernikahan. Peneliti memilih mahasiswa sebagai salah satu sampel dari penelitian ini karena mahasiswa merupakan golongan terpelajar secara akademik dan mempunyai akses pergaulan serta teknologi informasi yang relatif lebih luas, sehingga secara logika minim melakukan penyimpangan. Namun realitanya justru banyak generasi muda yang berstatus sebagai mahasiswa melakukan hal di luar dugaan bahkan menyimpang, baik dari sisi moral maupun agama.

Seperti yang telah dijelaskan di atas bahwa seks pranikah merupakan salah satu kasus yang banyak dilakukan oleh mahasiswa. Ini dikarenakan banyak dari mereka yang berasal dari luar daerah, sehingga lokasi rumah yang berjauhan dari tempat kuliah membuat sebagian mahasiswa memilih tinggal di rumah sewa (kost) dan menjadikannya sebagai rumah kedua, terutama bagi mereka yang tidak memiliki keluarga di Kota Sorong.

Banyak hal positif yang didapat dari tinggalnya mahasiswa di kos-kosan ini, diantaranya adalah lebih mandiri. Namun juga tidak terlepas dari sisi negatif, yaitu kurangnya pengawasan dari pemilik kost, ditambah letak kamar kost yang terlalu terbuka (bebas pengunjung) membuat sebagian mahasiswa bisa melakukan segala sesuatu sesuka hatinya. Hal ini disebabkan kecenderungan pola hubungan sosial yang sangat renggang antara pemilik kost dengan penghuni. Hubungan penghuni dan pemilik lebih bersifat transaksional sehingga membuat kehidupan seksual di tempat kost menjadi sangat bebas. Interaksi yang dilakukan tanpa pengawasan yang baik, serta desain kos-kosan yang terbuka (untuk umum) ini memberikan kebebasan dan peluang bagi sebagian mahasiswa untuk melakukan atau mempraktekkan segala rasa ingin tahu yang dimilikinya, sehingga semakin dilarang semakin penasaran dan akhirnya mereka berani untuk mengambil resiko yaitu melakukan perilaku seks pranikah tanpa pertimbangan yang matang. Ini membuktikan bahwa tidak semua yang terpelajar dapat berperilaku baik.

Selain itu, dorongan-dorongan seksual tersebut juga akan meningkat dengan adanya penyebaran informasi melalui internet, foto, video dan lain-lain. Penyebaran informasi yang sedemikian cepat ditambah dengan keingintahuan yang begitu besar mengakibatkan sebagian mahasiswa mengalami perubahan pola pikir. Perubahan itu mempengaruhi cara pandang mahasiswa terhadap seksualitas dan membentuk perilaku seksual tersendiri. Perilaku seksual ini biasanya dilakukan 
karena kondisi lingkungan yang menunjang sehingga akan memberikan peluang bagi mahasiswa untuk melakukan hubungan seks pra nikah tanpa ada rasa takut. Dengan perilaku buruk itu pula para generasi muda saat ini rentan terhadap resiko gangguan kesehatan seperti penyakit HIV/AIDS, serta penyakit kelamin lainnya. Hal ini sejalan dengan teori behavioral sociology dari B.F Skinner yang juga termasuk dalam paradigma perilaku sosial, teori ini berusaha untuk menerangkan hubungan historis antara akibat tingkah laku masa lalu yang terjadi dalam lingkungan aktor dengan tingkah laku aktor yang terjadi sekarang. Artinya, teori tersebut menerangkan bahwa tingkah laku yang terjadi dimasa sekarang merupakan akibat dari tingkah laku yang terjadi di masa sebelumnya.

Selain kondisi lingkungan, perilaku seks pranikah biasanya juga dilakukan sebagai pembuktian cinta mereka kepada pasangan masing-masing yang tanpa disadari akan membahayakan diri sendiri, karena cinta merupakan persoalan atraksi magnetik yang tak dapat dikontrol, atau sebuah bentuk penyerahan diri yang berbahaya, atau sebuah tarian di tepi sembilu (welwood dalam Michail Reiss \& J. Mark Halstead, 1985). Namun yang dianggap sangat penting sebenarnya adalah kemampuan mereka untuk mengontrol diri sendiri (Melvin Kohn dalam T.O Ihromi, 1999). Seperti penelitian yang dilakukan oleh Kasmawati (2014:23) yang menyatakan bahwa kecenderungan mahasiswa melakukan hubungan seksual atas dasar rasa cinta, hubungan yang dijalani sudah lama, serta adanya unsur takut kehilangan sehingga ia melakukan hubungan seksual tanpa didasari ikatan pernikahan. Hal ini juga sesuai dengan yang diungkapkan oleh Max Weber bahwa "Seseorang yang sedang mengalami perasaan meluap-luap seperti cinta, kemarahan, ketakutan atau kegembiraan, dan secara spontan mengungkapkan perasaan itu tanpa refleksi, berarti sedang memperlihatkan tindakan afektif, tindakan itu benar-benar tidak rasional karena kurangnya pertimbangan logis, ideologi, atau kriteria rasionalitas lainnya" (D.P. Jhonson, 1986 : 221).

Selain itu juga tidak adanya peraturan seperti tempat khusus menerima tamu atau batas waktu berkunjung sehingga mereka dapat melakukan segalanya dengan bebas, seperti mengajak tamu langsung masuk ke dalam kamar hingga melakukan hubungan seks pranikah. Namun justru rumah kost yang bebas seperti inilah yang banyak diminati oleh generasi muda, terutama sebagian mahasiswa sebagai tempat tinggal sementara selama melakukan studi di perguruan tinggi. Kesempatan besar terhadap mahasiswa sebagai bagian dari generasi muda untuk berbuat sesuka hatinya juga dikarenakan kurangnya interaksi dan kunjungan dari orang tua. Padahal interaksi merupakan hal yang penting dan juga kunci dari semua kehidupan sosial (Kimball Young dan Raymond dalam Soerjono Soekanto:54). Dari kurangnya interaksi dan juga kunjungan dari orang tua tersebut membuat mahasiswa merasa semakin bebas dan mudah untuk melakukan perilaku menyimpang termasuk perilaku seks pranikah.

Penelitian ini adalah penelitian kualitatif yang bertujuan untuk mengungkapkan secara menyeluruh mengenai semua aspek yang terkait dengan perilaku seks pranikah yang mayoritas dilakukan oleh mahasiswa. Adapun rumusan masalah yang ingin penulis kemukakan dalam penelitian ini yaitu :

1. Apa motivasi generasi muda melakukan perilaku seks pranikah di Distrik Malaimsimsa Kota Sorong ?

2. Faktor apa yang mempengaruhi generasi muda melakukan perilaku seks pranikah di Distrik Malaimsimsa Kota Sorong ? 
3. Bagaimana upaya pemerintah dalam mengatasi perilaku seks pranikah yang dilakukan oleh generasi muda di Distrik Malaimsimsa Kota Sorong ?

\section{METODE PENELITIAN}

Penelitian ini dilakukan di Distrik Malaimsimsa Kota Sorong dan akan dilaksanakan pada bulan Desember 2016Januari 2017. populasi adalah seluruh generasi muda yang ada di Distrik Malaimsimsa Kota Sorong. Selain itu, sampel yang diambil tidak mutlak jumlahnya, artinya sampel yang akan diambil disesuaikan dengan kebutuhan data selama di lapangan. Adapun teknik pengambilan sampel yang digunakan dalam penelitian ini adalah purposive sampling (sampel bertujuan) yang biasanya disebut sebagai judge ment sampling. Purposive sampling merupakan pemilihan siapa subjek yang ada dalam posisi terbaik untuk memberikan informasi yang dibutuhkan.

\section{Teknik Pengumpulan Data}

Untuk dapat dilakukan suatu penelitian diperlukan data yang cukup lengkap yang didapat dari teknik pengumpulan data. Dalam penelitian ini teknik pengumpulan data yang digunakan adalah sebagai berikut :

1. Metode wawancara mendalam

2. Metode observasi

3. Metode penelusuran online

4. Kuesioner

\section{Teknik Analisis Data}

Analisis data kualitatif dilakukan apabila data empiris yang diperoleh adalah data kualitatif berupa kumpulan berwujud kata-kata dan bukan rangkaian angka serta tidak dapat disusun dalam kategorikategori/struktur klasifikasi. Data (dalam wujud kata-kata) mungkin telah dikumpulkan dalam aneka macam cara (observasi, wawancara, intisari dokumen, pita rekaman) dan biasanya "diproses" sebelum siap digunakan (melalui pencatatan, pengetikan, penyuntingan, atau alih-tulis), tetapi analisis kualitatif tetap menggunakan kata-kata yang biasanya disusun ke dalam teks yang diperluas dan tidak menggunakan perhitungan matematis atau statistika sebagai alat bantu analisis (Matthew B. Miles \& A. Michael Huberman dalam Ulber Silalahi).

Menurut Miles dan Huberman, bahwa kegiatan analisis terdiri dari tiga alur kegiatan yang terjadi secara bersamaan, yaitu reduksi data, penyajian data dan penarikan kesimpulan/verivikasi. Terjadi secara bersamaan berarti reduksi data, penyajian data, dan penarikan kesimpulan/verivikasi sebagai sesuatu yang jalin menjalin merupakan proses siklus dan interaktif pada saat sebelum, selama dan sesudah pengumpulan data dalam bentuk sejajar untuk membangun wawasan umum yang disebut "analisis".

\section{Reduksi Data}

Reduksi data merupakan suatu bentuk analisis yang menajamkan, menggolongkan, mengarahkan, membuang yang tidak perlu, dan mengorganisasis data sedemikian rupa hingga kesimpulankesimpulan finalnya dapat ditarik dan diverifikasi. Reduksi data atau proses transformasi ini berlanjut terus sesudah penelitian lapangan, sampai laporan akhir lengkap tersusun. Jadi, dalam penelitian kualitatif, "reduksi data" tidak perlu mengartikannya sebagai kuantifikasi. Data kualitatif dapat disederhanakan dan ditransformasikan dalam aneka macam cara : melalui seleksi ketat, melalui ringkasan atau uraian singkat, menggolongkan dalam suatu pola yang lebih luas dan sebagainya.

\section{Penyajian Data}

Alur kedua yang penting dalam kegiatan analisis dalam penelitian kualitatif adalah penyajian data, penyajian data dalam penelitian kualitatif ini dapat dilakukan dalam berbagai jenis seperti matriks, grafik, jaringan dan bagan. Namun dalam penelitian 
ini penulis menyajikannya dengan menggunakan tabulasi data, yaitu penyajian data ke dalam bentuk tabel atau diagram untuk memudahkan pengamatan atau evaluasi.

Semuanya dirancang guna menggabungkan informasi yang tersusun dalam suatu bentuk yang padu dan mudah untuk dipahami. Dengan demikian peneliti dapat melihat apa yang sedang terjadi dan menentukan apakah menarik kesimpulan yang benar ataukah terus melangkah melakukan analisis menurut saran yang dikiaskan oleh penyajian sebagai sesuatu yang mungkin berguna. Jadi, penyajian data merupakan bagian dari analisis.

\section{Menarik Kesimpulan}

Kegiatan analisis yang ketiga adalah menarik kesimpulan dan verifikasi. Ketika kegiatan pengumpulan data dilakukan, peneliti mulai mencari arti benda-benda, mencatat keteraturan, pola-pola, penjelasan, konfigurasi-konfigurasi yang mungkin, alur sebab akibat, dan proposisi. Artinya kesimpulan akhir yang ditulis merupakan rangkaian keadaan dari yang belum jelas kemudian meningkat sampai pada pernyataan yang telah memiliki landasan yang kuat dari proses analisis terhadap fenomena yang ada.

\section{HASIL dan PEMBAHASAN}

\section{A. Gambaran Umum Lokasi Penelitian}

Dalam bagian ini akan diuraikan gambaran umum tentang profil Distrik Malimsimsa Kota Sorong, yaitu meliputi keadaan geografis dan demografi Distrik tahun 2014.

\section{Data Profil Distrik Malaimsimsa Kota Sorong}

Distrik Malaimsimsa merupakan salah satu Distrik yang dimekarkan dari Distrik Sorong Utara atas dasar kebijakan Walikota Sorong dengan meresmikan kelembagaan dan pelantikan pejabat Kepala Distrik dan Kelurahan se-Distrik Malaimsimsa di lingkungan pemerintahan Kota Sorong berdasarkan surat keputusan Walikota Sorong nomor : 021.2/2/06/BKD/2014 tanggal 13 februari 2014 bertepat di gedung Samusiret Kantor Walikota Sorong sekaligus wilayah bawahan meliputi kelurahan Klagete, kelurahan Malamso, kelurahan Malaingkedi dan keluarahan Klabulu dengan luas wilayah 98,04 $\mathrm{Km}^{2}$ dan jumlah penduduk 25.314 jiwa, untuk kepentingan penyelenggaraan pemerintahan, pembangunan serta pembinaan kemasyarakatan.

Untuk menjawab tujuan pemekaran distrik dan keluarahan adalah memenuhi kebutuhan warga masyarakat antara lain; perluasan penduduk, pemberdayaan ekonomi kerakyatan, infrastruktur dan pelayanan administrasi untuk mempermudah serta memperpendek rentang kendali pelayanan terhadap warga masyarakat. Terkait dengan hal tersebut, maka sudah tentu menjadi tanggung jawab pemerintah untuk memperdayakan distrik dan kelurahan sesuai dengan fungsi dan kedudukannya sehingga dapat menjadi ujung tombak pemerintahan ditingkat bawah dalam member pelayanan kepada masyarakat.

Tabel 1. Luas wilayah Distrik Malaimsimsa Kota Sorong

\begin{tabular}{lll}
\hline No & Kelurahan & Luas Wilayah \\
\hline 1 & Klagete & $20.00 \mathrm{Km}^{2}$ \\
\hline 2 & Malamso & $24.45 \mathrm{Km}^{2}$ \\
\hline 3 & Malaingkedi & $27.00 \mathrm{Km}^{2}$ \\
\hline 4 & Klabulu & $26.59 \mathrm{Km}^{2}$ \\
\hline & Jumlah & $\mathbf{9 8 . 0 4} \mathbf{K m}^{2}$ \\
\hline
\end{tabular}

Sumber : Data Distrik Malaimsimsa, Januari 2017 
Batas-batas Wilayah Distrik Malaimsimsa

Tabel 2. Distrik Malaimsimsa

\begin{tabular}{lll}
\hline Sebelah utara berbatasan dengan & $\begin{array}{l}\text { Kelurahan } \\
\text { Maladummes }\end{array}$ & Saoka \\
\hline Sebelah selatan berbatasan dengan & $\begin{array}{l}\text { Kelurahan Klasabi Distrik Sorong } \\
\text { Manoi }\end{array}$ \\
\hline Sebelah timur berbatasan dengan & $\begin{array}{l}\text { Kelurahan Malanu Distrik Sorong } \\
\text { Utara }\end{array}$ \\
\hline Sebelah barat berbatasan dengan & $\begin{array}{l}\text { Kelurahan Remu Utara Distrik } \\
\text { Sorong }\end{array}$ & \\
\hline
\end{tabular}

Sumber : Data Distrik Malaimsimsa, Januari 2017
2. Kondisi Geografis Distrik
Malaimsimsa Kota Sorong
a) Ketinggian tanah dari permukaan
laut : $3 \mathrm{~m} \mathrm{DPL}$
c) Kelembapan udara
: $87 \%$
d) Suhu udara rata-rata
b) Banyaknya curah hujan

$$
\text { : } 23,1^{0} \mathrm{C}-33,07^{0} \mathrm{C}
$$

$$
\text { : } 2.91 \mathrm{~mm} / \text { Tahun }
$$

\section{Sarana Umum}

\section{Tabel 3 Sarana Pendidikan}

\begin{tabular}{lllllll}
\hline No & Kelurahan & PAUD & SD & SMP & SMA & PTN/S \\
1 & Klagete & 1 & 1 & - & - & - \\
2 & Malamso & 1 & 2 & - & - & 1 \\
3 & Malaingkedi & 2 & - & 1 & 2 & - \\
4 & Klabulu & 2 & 2 & - & - & 2 \\
& Jumlah & $\mathbf{6}$ & $\mathbf{5}$ & $\mathbf{1}$ & $\mathbf{2}$ & $\mathbf{3}$ \\
\hline
\end{tabular}

Sumber : Data Distrik Malaimsimsa, Januari 2017

Tabel 4 Sarana Tempat Ibadah

\begin{tabular}{llllll}
\hline No & Kelurahan & Gereja & Masjid & Wihara & Pure \\
1 & Klagete & 5 & 1 & - & - \\
2 & Malamso & 4 & 1 & - & - \\
3 & Malaingkedi & 4 & 2 & - & - \\
4 & Klabulu & 1 & 3 & - & - \\
& Jumlah & $\mathbf{1 4}$ & $\mathbf{7}$ & - & - \\
\hline
\end{tabular}

Sumber : Data Distrik Malaimsimsa, Januari 2017

\section{Tabel 5. Sarana Kesehatan}

\begin{tabular}{llll}
\hline No & Kelurahan & Rumah Sakit Umum & Puskesmas/Pustu \\
1 & Klagete & - & 1 \\
2 & Malamso & 1 & - \\
3 & Malaingkedi & - & - \\
4 & Klabulu & - & - \\
& Jumlah & $\mathbf{1}$ & $\mathbf{1}$ \\
\hline
\end{tabular}

Sumber : Data Distrik Malaimsimsa, Januari 2017

\section{Bidang Pemerintahan}

a. Tabel 6. Data Nominatif Pegawai Negeri Sipil ( PNS )

\begin{tabular}{llll}
\hline No & Distrik/Kelurahan & PNS & Honorer \\
\hline
\end{tabular}




\begin{tabular}{llll}
\hline 1 & Malaimsimsa & 11 & 3 \\
2 & Klagete & 9 & 1 \\
3 & Malamso & 4 & 3 \\
4 & Malaingkedi & 12 & - \\
5 & Klabulu & 4 & - \\
& Jumlah & $\mathbf{4 0}$ & $\mathbf{7}$ \\
\hline
\end{tabular}

Sumber : Data Distrik Malaimsimsa, Januari 2017

Tabel 7. Data Jumlah RT/RW

\begin{tabular}{llll} 
No & Kelurahan & RW & RT \\
1 & Klagete & 4 & 20 \\
2 & Malamso & 4 & 14 \\
3 & Malaingkedi & 4 & 19 \\
4 & Klabulu & 4 & 15 \\
& Jumlah & $\mathbf{1 6}$ & $\mathbf{6 8}$ \\
\hline
\end{tabular}

Sumber : Data Distrik Malaimsimsa, Januari 2017

Tabel 8. Data Jumlah Penduduk

\begin{tabular}{lllll} 
No & Kelurahan & Laki - Laki & Perempuan & Jumlah \\
1 & Klagete & 2.550 Jiwa & 2.520 & 5.070 \\
2 & Malamso & 2.426 Jiwa & 2.215 & 4.641 \\
3 & Malaingkedi & 4.525 Jiwa & 4.430 & 8.955 \\
4 & Klabulu & 3.425 Jiwa & 3.223 & 5.548 \\
& Jumlah & $\mathbf{1 2 . 9 2 6 ~ J i w a ~}$ & $\mathbf{1 2 . 3 8 8}$ & $\mathbf{2 5 . 3 1 4}$ \\
\hline
\end{tabular}

Sumber : Data Distrik Malaimsimsa, Januari 2017

\section{Pembahasan Hasil Analisis}

\section{Karakteristik Responden}

Banyaknya sampel dari penelitian ini adalah 22 responden, yang terdiri dari 20 mahasiswa kost baik laik-laki maupun perempuan yang pernah atau sedang berpacaran, 1 tokoh masyarakat dan 1 tokoh agama yang ada di Distrik Malaimsimsa Kota Sorong. Hasil analisis karakteristik responden dapat diuraikan dengan menggunakan tabel sebagai berkut:

Umur

Klasifikasi responden berdasarkan

umur adalah 20 tahun sebanyak 2

Tabel 9. Gambaran karakteristik responden berdasarkan jenis kelamin

\section{Jenis Kelamin}

Laki-laki

Perempuan

Jumlah

Sumber : Data primer, Januari 2017

Tabel 9 menunjukkan bahwa frekuensi terbesar berdasarkan jenis kelamin responden adalah perempuan yaitu sebanyak responden, 21 tahun sebanyak 4 responden, 22 tahun sebanyak 6 responden, 23 tahun sebanyak 7 responden, 24 tahun 1 responden, 35 tahun 1 responden dan 58 tahun 1 responden. Hal ini menunjukkan bahwa frekuensi terbesar umur responden adalah 23 tahun yaitu sebanyak 7 responden, sedangkan frekuensi terkecil adalah umur 24 tahun sebanyak 1 responden, umur 35 tahun sebanyak 1 responden, dan 58 tahun sebanyak 1 responden.

Jenis Kelamin

\section{Frekuensi}

7

15

22 
penelitian ini sampel penelitian di dominasi oleh perempuan.

\section{Agama}

Klasifikasi responden berdasarkan agama adalah islam sebanyak 18 responden, kristen protestan 3 responden, dan khatolik 1 responden. Hal ini menunjukkan bahwa frekuensi terbesar berdasarkan keyakinan (agama) responden adalah Islam yaitu sebanyak 18 responden, sedangkan frekuensi terkecil adalah khatolik yaitu sebanyak 1 responden.

\section{Profesi}

Klasifikasi responden berdasarkan profesi adalah mahasiswa sebanyak 20 responden, tokoh agama 1 responden dan tokoh masyarakat 1 responden. Ini menunjukkan bahwa frekuensi terbesar menurut profesi adalah mahasiswa yaitu sebanyak 20 responden, sedangkan frekuensi terkecil adalah tokoh agama yaitu 1 responden dan tokoh masyarakat 1 responden. Dalam penelitian ini menggunakan dua cara untuk mendapatkan data, yaitu pengisian kuesioner pilihan ganda yang diisi oleh mahasiswa dan selanjutnya akan disajikan dengan menggunakan tabulasi data, serta wawancara mendalam bersama tokoh agama dan tokoh masyarakat guna mendapatkan kelengkapan data mengenai fenomena seks pranikah di Distrik Malaimsimsa Kota Sorong.

1) Motivasi Generasi Muda Melakukan Perilaku Seks Pranikah

Berdasarkan konsep perilaku menyimpang bahwa suatu perilaku atau tindakan itu dianggap menyimpang apabila menurut anggapan sebagian besar masyarakat (minimal disuatu kelompok atau komunitas) perilaku atau tindakan tersebut di luar kebiasaan, aturan atau nilai dan norma yang berlaku (Budirahayu, 2009:3). Seperti halnya seks bebas dikalangan mahasiswa kost yang dilakukan oleh pasangan di luar pernikahan merupakan hal yang bertentangan dengan norma yang berlaku baik agama maupun masyarakat yang kemudian akan membawa dampak buruk bagi individu pelakunya yang tidak terlepas dari pengaruh atau latar belakang yang menyebabkannya.

Motivasi lain yang dapat mempengaruhi seorang mahasiswa melakukan perilaku seks pranikah adalah dorongan rasa ingin tahu yang besar untuk mencoba segala hal yang belum diketahui. Hal tersebut merupakan ciri-ciri generasi muda pada umumnya, yaitu mereka ingin mengetahui banyak hal yang dapat dipuaskan serta diwujudkannya melalui pengalaman sendiri. Hal ini diperkuat dengan data tabel berikut :

\section{Tabel 10. Mahasiswa yang pernah mempunyai pacar}

\begin{tabular}{lll}
\hline No & Variabel & Frekuensi \\
1 & Ya & $\mathbf{2 0}$ \\
2 & Tidak & - \\
& Jumlah & $\mathbf{2 0}$ \\
\hline
\end{tabular}

Sumber : Data primer, Januari 2017

Berdasarkan tabel 10 diketahui bahwa mahasiswa yang menjawab pernah mempunyai pacar sebanyak 20 orang. Hal ini menunjukkan bahwa seluruh mahasiswa yang dijadikan sampel penelitian di Distrik Malaimsimsa Kota Sorong pernah mempunyai pacar. Adapun frekuensi mahasiswa yang menjawab berpacaran mulai umur 13 tahun sebanyak 2 orang, 15 tahun 1 orang, 16 tahun sebanyak 2 orang, 17 tahun sebanyak 8 orang dan 18 tahun sebanyak 7 orang. Hal ini menunjukkan bahwa sejak duduk di bangku SMP, 2 diantara mahasiswa yang dijadikan sampel sudah mengenal istilah berpacaran. Selain itu, mahasiswa yang menjawab saat ini 
memiliki pacar adalah sebanyak 15 orang dan 5 diantaranya tidak memiliki pacar. Serta 8 orang menjawab sangat tahu tentang seks pranikah dan 12 diantaranya menjawab cukup tahu. Hal ini menunjukkan bahwa seluruh mahasiswa yang dijadikan sampel memiliki pengetahuan mengenai seks pranikah.

Tabel .11

Pendapat Mahasiswa Tentang Seks Pranikah

\begin{tabular}{|l|l|l|}
\hline No & Variabel & Frekuensi \\
\hline 1 & Setuju & 4 \\
\hline 2 & Ragu-Ragu & 5 \\
\hline 3 & Tidak Setuju & 11 \\
\hline & Jumlah & $\mathbf{2 0}$ \\
\hline
\end{tabular}

Sumber : Data primer, Januari 2017

Berdasarkan tabel 4.21 diketahui bahwa 4 orang setuju dengan perilaku seks pranikah, 5 orang menjawab ragu-ragu dan 11 diantaranya tidak setuju. Tabel tersebut menunjukkan jika sebagian besar mahasiswa tidak setuju dengan adanya perilaku seks pranikah.

Tabel 4.22

Pengetahuan mahasiswa Tentang Larangan Agama Terhadap Seks Pranikah

\begin{tabular}{|l|l|l|}
\hline No & Variabel & Frekuensi \\
\hline 1 & Ya & 20 \\
\hline 2 & Tidak & - \\
\hline & Jumlah & 20 \\
\hline
\end{tabular}

Sumber : Data primer, Januari 2017

Berdasarkan tabel 4.22 diketahui bahwa 20 orang menjawab mengetahui larangan agama mengenai seks pranikah. Hal ini menunjukkan seluruh mahasiswa yang dijadikan sampel penelitian di Distrik Malaimsimsa Kota Sorong mengetahui jika agama melarang adanya perilaku seks pranikah.

Tabel 4.23

Orang Pertama Yang Melakukan Hubungan Seks Dengan Mahasiswa

\begin{tabular}{|l|l|l|}
\hline No & Variabel & Frekuensi \\
\hline 1 & Pacar & 20 \\
\hline 2 & Saudara & - \\
\hline 3 & Lainnya & - \\
\hline & Jumlah & $\mathbf{2 0}$ \\
\hline
\end{tabular}

Sumber : Data primer, Januari 2017

Berdasarkan tabel 4.23

diketahui bahwa seluruh mahasiswa

yang dijadikan sampel penelitian di

Distrik Malaimsimsa Kota Sorong melakukan hubungan seks pertama kali yaitu bersama pacar.

\section{Tabel.12}

Umur Pertama Kali Mahasiswa Melakukan Hubungan Seks Pranikah

\begin{tabular}{|l|l|l|}
\hline No & Variabel & Frekuensi \\
\hline 1 & 15 Tahun & 1 \\
\hline 2 & 16 Tahun & 5 \\
\hline 3 & 17 Tahun & 2 \\
\hline
\end{tabular}




\begin{tabular}{|l|l|l|}
\hline 4 & 18 Tahun & 4 \\
\hline 5 & 20 Tahun & 8 \\
\hline & Jumlah & $\mathbf{2 0}$ \\
\hline
\end{tabular}

Sumber : Data primer, Januari 2017

Berdasarkan tabel 4.24 diketahui bahwa mahasiswa yang menjawab melakukan hubungan seks pranikah pertama kali pada umur 15 tahun 1 orang, umur 16 tahun sebanyak 5 orang, umur 17 tahun Tabel 4.25

\section{Perasaan Mahasiswa Saat Pertama Kali Melakukan Hubungan Seks Pranikah}

\begin{tabular}{|l|l|l|l|}
\hline No & Variabel & Ket. & Frekuensi \\
\hline 1 & Takut & - & 11 \\
\hline 2 & Senang & - & 5 \\
\hline 3 & Bingung & - & 2 \\
\hline 4 & Lainnya & $\begin{array}{r}- \text { Biasa Saja } \\
\text { Takut, senang, bingung }\end{array}$ & 1 \\
\hline & Jumlah & - & $\mathbf{2 0}$ \\
\hline
\end{tabular}

Sumber : Data primer, Januari 2017

Berdasarkan tabel 4.25 diketahui bahwa perasaan mahasiswa yang menjawab takut pada saat pertama kali melakukan hubungan seks pranikah adalah sebanyak 11 orang, 5 orang menjawab senang, 2 orang menjawab bingung, 1 orang menjawab biasa saja dan 1 orang menjawab antara takut, senang dan bingung. Hal ini menunjukkan bahwa sebagian besar mahasiswa merasakan ketakutan pada saat pertama kali melakukan hubungan seks pranikah.

Tabel .13

Motivasi Mahasiswa Melakukan Perilaku Seks Pranikah

\begin{tabular}{|l|l|l|}
\hline No & Variabel & Frekuensi \\
\hline 1 & Suka Sama Suka & 10 \\
\hline 2 & Pengaruh Teman & 3 \\
\hline 3 & Kepuasan / Kesenangan & 5 \\
\hline 4 & Ingin Tahu & 1 \\
\hline & Jumlah & $\mathbf{2 0}$ \\
\hline
\end{tabular}

Sumber : Data primer, Januari 2017

Berdasarkan tabel 4.26

diketahui bahwa mahasiswa yang menjawab termotivasi melakukan perilaku seks pranikah karena suka sama suka adalah sebanyak 10 orang, 3 orang menjawab karena pengaruh teman, 5 orang menjawab karena

Tabel .14

Permintaan/Pemberian Bayaran Kepada Pasangan Pada Saat Melakukan Hubungan Seks Pranikah

\begin{tabular}{|l|l|l|}
\hline No & Variabel & Frekuensi \\
\hline
\end{tabular}

kepuasan/kesenangan, dan 1 orang menjawab karena memiliki rasa ingin tahu yang tinggi. Hal ini menunjukkan bahwa perasaan suka sama sukalah yang mendominasi mahasiswa untuk melakukan perilaku seks pranikah. 


\begin{tabular}{|l|l|l|}
\hline 1 & Ya & 4 \\
\hline 2 & Tidak & 16 \\
\hline & Jumlah & $\mathbf{2 0}$ \\
\hline
\end{tabular}

Sumber : Data primer, Januari 2017

Berdasarkan tabel 4.27

diketahui bahwa mahasiswa yang menjawab pernah meminta/memberi bayaran kepada pasangannya pada saat melakukan hubungan seks pranikah adalah sebanyak 3 orang

Tabel .15

Bentuk Bayaran/Imbalan Pada Saat Melakukan Hubungan Seks Pranikah

\begin{tabular}{|l|l|l|}
\hline No & Variabel & Frekuensi \\
\hline 1 & Uang & 3 \\
\hline 2 & Barang & 1 \\
\hline 3 & Tidak Menerima & 16 \\
\hline & Jumlah & $\mathbf{2 0}$ \\
\hline
\end{tabular}

Sumber : Data primer, Januari 2017

Berdasarkan tabel 4.28

diketahui bahwa mahasiswa yang

menjawab pernah

menerima/memberi bayaran/imbalan

Tabel .16

dan 17 lainnya menjawab tidak. Tabel tersebut menunjukkan bahwa sebagian besar mahasiswa tidak pernah memberi atau meminta bayaran pada saat melakukan hubungan seks pranikah.

Keinginan Mahasiswa Untuk Berhenti Melakukan Perilaku Seks Pranikah

\begin{tabular}{|l|l|l|}
\hline No & Variabel & Frekuensi \\
\hline 1 & Ada & 9 \\
\hline 2 & Ragu-Ragu & 6 \\
\hline 3 & Tidak & 5 \\
\hline & Jumlah & $\mathbf{2 0}$ \\
\hline
\end{tabular}

Sumber : Data primer, Januari 2017

Berdasarkan tabel 4.29

diketahui bahwa mahasiswa yang menjawab ada keinginan untuk berhenti melakukan perilaku seks pranikah adalah sebanyak 9 orang, 6 orang menjawab ragu-ragu, dan 5

\section{Upaya Pemerintah Dalam Mengatasi} Perilaku Seks Pranikah

Kebebasan dalam hidup adalah hak asasi setiap manusia, namun kebebasan tersebut tentu saja merupakan kebebasan yang bertanggung jawab. Untuk mencegah kebebasan yang tidak terbatas maka terciptalah norma-norma yang membatasi kebebasan seseorang berupa uang adalah sebanyak 3 orang, berupa barang 1 orang dan 16 orang diantaranya mengaku tidak menerima bayaran/imbalan.

\section{Analisis Motivasi Generasi Muda ...}

orang menjawab tidak ada keinginan untuk berhenti melakukan perilaku seks pranikah. Hal ini menunjukkan bahwa sebagian besar mahasiswa memiliki keinginan untuk berhenti melakukan perilaku seks pranikah. agar tidak melanggar nilai-nilai moral yag berlaku di masyarakat. Di Indonesia sendiri terdapat norma sosial dan norma hukum yang membatasi pergaulan seseorang agar tidak terjerumus ke dalam hal-hal yang menyimpang seperti halnya perilaku seks pranikah. Adapun normanorma sosial tersebut diantaranya : 
1. Norma agama, yaitu peraturan sosial yang sifatnya mutlak sebagaimana penafsirannya dan tidak dapat di tawar-tawar atau diubah ukurannya karena berasal dari Tuhan

2. Norma kesusilaan, yaitu peraturan sosial yang berasal dari hati nurani yang menghasilkan akhlak, sehingga seseorang dapat Norma-norma tersebut tentu saja dengan tegas melarang adanya seks pranikah yang merusak moral siapapun yang melakukannya. Yang kedua, norma hukum Indonesia yang mengatur tentang pelanggaran seks bebas (seks pranikah) adalah UU No. 44 tahun 2008 tentang pornografi dan KUHP pasal 284. Walaupun pada kenyataannya perangkat hukum tersebut masih rapuh karena belum bisa menindak tegas para pelaku seks pranikah. Pelaku seks pranikah tidak dapat disebut melanggar UU pornografi bila perbuatan tersebut tidak dimaksudkan untuk konsumsi masyarakat. Juga tidak dapat dikategorikan zina menurut KUHP, karena zina menurut KUHP merupakan delik aduan, jadi mereka baru bisa dikatakan berzina bila ada yang mengadukan.

Di Indonesia khususnya di Kota Sorong, pemerintah dinilai kurang serius dalam mengatasi kasus seks pranikah di kalangan generasi muda, bahkan saat ini perilaku seks pranikah sudah sampai pada tingkat yang mengkhawatirkan. Jika tidak segera diantisipasi, akan beresiko bagi pengelolaan kependudukan Indonesia dan memicu rendahnya kualitas generasi bangsa Indonesia.

Untuk mengetahui upaya yang dilakukan pemerintah dalam mengatasi perilaku seks pranikah khususnya di Distrik Malaimsimsa Kota Sorong, penulis melakukan wawancara bersama sekretaris membedakan antara mana yang dianggap baik dan mana yang dianggap buruk

3. Norma kesopanan, yaitu peraturan sosial yang mengarah pada hal-hal yang berkenaan dengan bagaimana seseorang harus bertingkah laku yang wajar dalam kehidupan bermasyarakat.

Distrik Malaimsimsa Kota Sorong guna mendapat tanggapan mengenai pendapat dan solusi atas maraknya perilaku seks pranikah tersebut. Berikut adalah hasil kutipan wawancaranya :

"Seks pranikah atau biasa dikenal dengan istilah seks bebas merupakan suatu bentuk pergaulan yang tidak sesuai dengan norma kehidupan bermasyarakat, namun realita yang ada justru perilaku tersebut sudah menjadi konsumsi yang biasa pada gaya pacaran generasi muda masa kini. Jika hal ini di biarkan secara terus-menerus maka akan merusak moral generasi bangsa Indonesia"

Penulis juga melakukan wawancara mengenai solusi atas maraknya perilaku seks pranikah yang dilakukan oleh generasi muda di Distrik Malimsimsa Kota Sorong, berikut adalah hasil kutipan wawancaranya :

"Salah satu rusaknya moral generasi bangsa Indonesia adalah akibat dari pergaulan yang salah, seperti halnya kasus seks pranikah yang sedang marak dilakukan oleh generasi muda zaman skarang. Untuk mengurangi maraknya perilaku tersebut diharapkan agar pemerintah setempat sesering mungkin mengadakan sosialisasi seperti sosialisasi tentang program Penyiapan Kehidupan Berkeluarga Bagi Remaja (PKBR) sebagai antisipasi meningkatnya perilaku seks bebas di kalangan generasi muda saat ini. 
Pemerintah juga harus meningkatkan program sosialisasi yang berkaitan dengan kesehatan reproduksi remaja. Untuk itu pemerintah perlu meningkatkan adanya Pusat Informasi dan Konseling Remaja (PIK-Remaja) di daerah-daerah setempat serta harus terus dipantau."

\section{KESIMPULAN DAN SARAN}

Berdasarkan penelitian yang telah dilaksanakan mengenai perilaku seks pranikah yang dilakukan oleh mahasiswa kost di Distrik Malaimsimsa Kota Sorong, maka penulis menarik kesimpulan sebagai berikut :

1. Motivasi generasi muda khususnya mahasiswa yang ada di Distrik Malaimsimsa Kota Sorong melakukan perilaku seks pranikah dikarenakan atas dasar rasa cinta, hubungan yang dijalani sudah lama dengan didominasi oleh perasaan kedekatan dan gairah yang tinggi terhadap pasangannya, serta adanya unsur takut kehilangan sehingga ia melakukan hubungan seksual tanpa didasari ikatan pernikahan.

2. Seks pranikah juga dipengaruhi oleh beberapa faktor, diantaranya faktor interaksi dengan teman dan pemilik rumah sewa (kost), dimana teman yang satu dengan yang lain saling melindungi dan merahasiakan, kurangnya interaksi antara mahasiswa dengan pemilik rumah sewa (kost) juga dapat memicu terjadinya perilaku seks panikah, dimana interaksi yang mereka jalani hanyalah sebatas transaksional.

3. Kasus seks pranikah tersebut memaksa pemerintah untuk segera ikut serta dalam menanggulanginya, diantaranya dengan cara melakukan sosialisasi seperti sosialisasi tentang program Penyiapan Kehidupan Berkeluarga Bagi Remaja (PKBR) sebagai antisipasi meningkatnya perilaku seks bebas di kalangan generasi muda saat ini. Pemerintah juga harus meningkatkan program sosialisasi yang berkaitan dengan kesehatan reproduksi remaja. Untuk itu pemerintah perlu meningkatkan adanya Pusat Informasi dan Konseling Remaja (PIK-Remaja) di daerahdaerah setempat serta membutuhkan pemantauan khusus.

\section{DAFTAR PUSTAKA}

Anna Salisa, 2010. Perilaku Seks Pranikah Di Kalangan Remaja (Studi Deskriptif Kualitatif Tentang Perilaku Seks Pranikah Di Kalangan Remaja Kota Surakarta. Skripsi diterbitkan. Surakarta. Fakultas Ilmu Sosial dan Ilmu Politik. Universias Sebelas Maret.

Burhan Bungin, 2011. Penelitian Kualitatif, Kencana : Jakarta

Budirahayu, Tuti, 2009. Sosiologi Perilaku

Menyimpang. PT.Revka Petra Media : Surabaya

Doyle Paul Johnson, 1986. Teori Sosiologi Klasik dan Modern. Jilid 1. Terjemahan Robert MZ Lawang. Gramedia : Jakarta

George Ritzer, 2010. Sosiologi Ilmu Pengetahuan Berparadigma Ganda. PT RajaGrafindo Persada : Jakarta

George Ritzer, 2003. Sosiologi Ilmu Pengetahuan Berparadigma Ganda, Ed.1, Cet.4. PT RajaGrafindo Persada : Jakarta

Kasmawati. 2014. Seks Bebas Dikalangan Mahasiswa Kost Kelurahan Tanjung Ayun Sakti. Skripsi diterbitkan. Tanjung Pinang. Fakultas Ilmu 
Sosial dan Ilmu Politik. Universitas Maritim Raja Ali Haji.

Michail Reiss \& J. Mark Halstead, 2006. Pendidikan Seks Bagi Remaja. Alenia Press : Yogyakarta

Soerjono Soekanto, 2012. Sosiologi Suatu Pengantar. PT RajaGrafindo Persada : Jakarta

Sosiator, 2015. Paradigma Perilaku Sosial. (Online)

http://sosiatoris.mywapblog.com/teor i-paradigma-perilaku-sosial.xhtml (diakses pada tanggal 01 Agustus 2016)

T.O. Ihromi, 2004. Bunga Rampai Sosiologi Keluarga. Yayasan Obor Indonesia : Jakarta

Ulber Silalahi, 2012. Metode Penelitian Sosial. PT. Refika Aditama : Bandung

Wikipedia Bahasa Indonesia, 2016. Remaja. (online) https://ms.m.wikipedia.org/wiki/Rem $\underline{\text { aja }}$ (diakses pada tanggal 29 juli 2016)

Wikipedia Bahasa Indonesia, 2016. Negara Sekuler. (online) https://id.m.wikipedia.org/wiki/Nega ra_sekuler (diakses pada tanggal 26 Juli 2016)

Wikipedia bahasa Indonesia, 2016. Interaksi Sosial. (online) https://id.m.wikipedia.org/wiki/Intera ksi_sosial (diakses pada tanggal 04 Agustus 2016) 